Some of my first slides I find useful to this day, and every day adds experience, or a word from some friend working in the same field. The difficulty of making sections is a myth.

Cambridge, Mass., Oct. 3 r.

AUG. F. Foerste.

\section{Search for Gems and Precious Stones.}

IN reference to the interesting article of Prof. P. L. Simmonds on the search for gems and precious stones, read before the Society of Arts of England recently, reprinted in your issue of Oct. I4, allow me to suggest a few corrections. Professor Simmonds estimates the yield of the Brazilian diamond-mines at $£ 800,000$ annually, while a little later on he says that the yield has dwindled to 24,000 carats, which at the outside will not yield more than $£ 2$ to $£ 3$ a carat, and that of India, Borneo, and Australia at $£ 200,000$, when these latter figures would probably cover the annual product of Brazil as well as that of the other three countries named. Australia produces so very little as scarcely to be a factor in the computation. Even before the opening of the African mines, in 1867 , the estimated value of the product of Brazil from i 86 I to I 867 was only $£_{\mathrm{I}}, 888$, ooo, or something over $£ 300,000$ per annum, at a time when Brazilian diamonds commanded a higher price than at present, and now they produce much less. His statement that the opal is out of fashion would have been true several years ago, but is not to-day, when more of these stones are sold, and at better prices, than ever before.

The carat is given as 3.174 grains ; whereas, since there are 151.5 English diamond carats in an English Troy ounce of 480 grains, an English carat would be 3.1683168 Troy grains, or, less exact, 3.I 68 . A diamond carat is always divided into four diamond grains equalling .792074 of a Troy grain. If 31.103 grams equal an English Troy ounce, a carat would be .205304 of a gram.

An international syndicate composed of London, Paris, and Amsterdam jewellers, wishing to establish a uniform carat, in 1877 confirmed .205 , however, as the true value of a carat, in which case we have 151.76 carats in an ounce Troy.

These may seem trifling differences, but yet they are enough to affect a $\$ 10,000$ lot of diamonds, worth $\$$ I oo a carat, to the amount of $\$ 4.83$ between the 3.174 carat and the 3.I68 carat, and $\$ 19.80$ between the former and the syndicate carat.

It would perhaps have been better to make the reference to imperial jade, which he mentions several times, under the head of the jade-quarries of Burma, as this (Feitsui imperial jade is jadeite, not jade, and is generally only emerald green in spots or streaks, the mass being a dead white, lending a vividness to the green which occasionally almost rivals the emerald, and has the hardness of 7 .

Of the articles of jade shown by the New Zealand Court at the colonial exhibition, England, Professor Simmonds says, “ Evidencing the skill of the Maoris in working this hard material, the second in this respect to the diamond, although much more fragile," etc. This would lead one to infer that the material possesses great hardness, when, in fact, the hardness of jade is only 6.5, less even than that of rock crystal, and it can be worked with sand, by which laborious means, undoubtedly, all of the aboriginal ornaments of the Maori were made. So far as its fragility is concerned, it is the toughest of all known minerals, and this is the reason why it is so difficult to work. It would require less time to polish twenty surfaces of agate, which is harder than jade, than it would to polish one of jade on the same wheel. Krantz, the mineral-dealer of Bonn, having a fifty-pound piece of jade which he wished broken into small hand specimens, a friend kindly offered him the use of a large half-ton trip hammer to break it with. At the first blow the hammer was demolished, and the jade was only fractured by being heated and thrown into cold water.

We frequently hear minerals or gems loosely spoken of as second or third in hardness to the diamond. On the Mohs scale of hardness, the diamond is represented by Io, the sapphire by 9 , topaz 8 , and quartz 7 ; but, although the difference on the scale is only $\mathbf{I}$, there is room for several substances between the diamond and the sapphire; and, as we have no such known substance in nature, we place diamond on ro. In reality, so great is the difference between these two substances, that, if the hardness of the sapphire is 9, that of the diamond would be fully Ioo, relatively to the rest of the scale. Professor Simmonds also says that coral has the hardness and brilliancy of agate. Quartz and agate are placed at 7 in the Mohs scale, whereas coral has only the hardness of about 3 , the same as that of marble (calcite), and can be scratched by fluorite. It is impossible to see how this opaque substance can be said to " shine like a garnet, with the tint of the ruby."

A word, in closing, about the hardness of agate and rock crystal. Mineralogically these are classed together at 7 ; but in reality the crystalline varieties should be 7 , and the crypto-crystalline varieties $7 \cdot 3$, since they will readily scratch quartz, and quartz will not scratch them.

New York, Oct. $3^{\mathrm{r}}$. GEORGE F. KUnZ.

\section{Living Lights.}

WE have noticed in your journal (Science, x. No. 246) a review of the book on phosphorescence called 'Living Lights.' The writer, it seems, must have made a very hasty perusal to have failed to see that the statements therein are not conjectural, but in each case are from individuals we are accustomed to honor as credible witnesses.

The fact of this review being in the columns of a science journal is, of course, the only reason for our interest in it. The most charitable construction which we can put on this surprising exhibition of lack of knowledge is that the reviewer did not notice the array of great names which support the statements of the book, for we cannot think that any one would knowingly dispute the words of such men - and naturalists.

The reviewer starts off by throwing discredit and ridicule on the entire world of luminosity, seemingly denying that attribute to all living objects. He says, "Not only do fire-flies fly, glow-worms glow, zoöphytes twinkle in the sea, but sea-anemones, alcyonarians, gorgonias, star-fishes, earth-worms, crabs, shell-fish, lizards, frogs, toads, fishes, birds, monkeys, and men must be added," etc.

We confess to embarrassment in approaching the task of replying to such, for one is impressed with the notion that some occult jest is intended; but again we are reminded of the character of the journal, and a feeling of surprise follows at the incomprehensible lack of knowledge displayed regarding the subject in hand.

The reviewer continues, " There is no excuse for conjectural illustrations, and ideal views of possible appearances." Shall we inform him that twelve of the plates in 'Living Lights' are process copies taken from lately published bulletins of M. Filhol, M. Dubois, and from sketches of the deep-water dredged objects obtained by the gentlemen of the ' Challenger,' ' Travaileur,' ' Porcupine,' ' Majenta,' and others, several of whom kindly furnished the author with advanced papers for use in his work?

Thus for twelve of the illustrations: for the remaining ones, it were absurd indeed to defend them. The former, as being matter not yet widely extant, some of it not published outside of society bulletins, may well be regarded as unfamiliar. The quotation which the reviewer takes from the book is treated so as to mislead. The author evidently meant to convey that it is difficult to represent the phenomenon of luminosity in marine animals, as their integrity is injured on exposure to air, though no question is entertained of their luminosity. A kindly review of this portion would rather praise the caution exhibited by the author in stating that the pictures may possibly not exactly portray the real appearance as it exists in the sea. The statements of the reviewer are so sweeping and (possibly) damaging among those not informed, it would seem advisable to state facts, though it is a humiliating thought that the brilliant work of so many eminent men should in such quarters be unknown.

It is but justice to do this, as the author of 'Living Lights' is at present beyond reach, at a distance from home, and of course unable to reply seasonably.

The statement, "zoöphytes twinkling in the sea" might well have covered the ground for one group, without enumerating "seaanemones, alcyonarians, gorgonias," etc., also ; but this enumeration will serve to suggest what objects concern us, as those arraigned for false attributes. We presume that few will deny the luminous gift to fire-flies, glow-worms, etc., which are mentioned in this connection. Let us, then, pass to the sea-anemone record. Colonel Pike of Brooklyn, an American naturalist not to be questioned, has given at length his testimony, and we know that the author himself has an experience as to their luminosity, which, 